\title{
Efektivitas Model Pembelajaran Problem Based Learning dan Problem Posing Ditinjau dari Kemampuan Pemecahan Masalah Matematika Siswa Kelas V SD
}

\author{
Ratna Dwi Anifah, Wahyudi
}

(C) 2020 JEMS (Jurnal Edukasi Matematika dan Sains)

This is an open access article under the CC-BY-SA license (https://creativecommons.org/licenses/bysa/4.0/) ISSN 2337-9049 (print), ISSN 2502-4671 (online)

\begin{abstract}
Abstrak:
Penelitian ini bertujuan untuk mengetahui efektivitas model PBL (Problem Based Learning) dan Problem Posing ditinjau dari kemampuan pemecahan masalah matematika kelas $\mathrm{V}$ sekolah dasar. Penelitian ini termasuk penelitian eksperimen semu. Metode dalam penelitian ini menggunakan desain quasi eksperimental dengan subjek penelitian seluruh siswa kelas $\mathrm{V}$ UPTD SPF SD Negeri Bringin 02 sebagai kelas eksperimen dan siswa kelas V UPTD SPF SD Negeri Bringin 01 sebagai kelas kontrol. Kelas eksperimen diberikan treatment dengan model Problem Posing dan kelas kontrol diberikan treatment dengan model Problem Based Learning (PBL). Teknik pengumpulan data dilakukan dengan observasi dan tes. Uji prasyarat menunjukkan kedua kelas homogen dan berdistribusi normal. Uji $\mathrm{T}$ menggunakan uji $\mathrm{t}$ Independent Sample Test yang menunjukkan thitung $>$ tabel yaitu 3,840 >1,998 dan signifikan $0,000<0,05$ yang artinya $\mathrm{H}_{0}$ ditolak dan $\mathrm{H}_{a}$ diterima. Hal ini menunjukkan adanya perbedaan efektivitas yang signifikan. Selanjutnya dilakukan uji normalitas gain yang menunjukkan model Problem Posing lebih efektif dibanding model Problem Based Learning $(P B L)$ ditinjau dari kemampuan pemecahan masalah.
\end{abstract}

Kata Kunci: PBL, Problem Posing, Kemampuan Pemecahan Masalah.

\section{Pendahuluan}

Era globalisasi menuntut setiap individu memiliki daya saing tinggi guna menghadapi setiap tantangan perkembangan zaman. Individu berdaya saing tinggi dapat diwujudkan dengan

Ratna Dwi Anifah, Universitas Kristen Satya Wacana

ratnaanifah@gmail.com

Wahyudi, Universitas Kristen Satya Wacana

Yudhi@staff.uksw.edu

\begin{abstract}
:
This study aims to determine the effectiveness of PBL (Problem Based Learning and Problem Posing models on the problem solving skill mathematics in grade $\mathrm{V}$ elementary school student. This study included quasi-experimental research. The method in this study used a quasi experimental design with research subjects throughout Elementary Scholl V grade student UPTD SPF Bringin 02 as an experimental class and students of class $\mathrm{V}$ Elementary School UPTD SPF Bringin 01 as the control class. Eksperiment class with Problem Posing model and control class with Problem Based Learning (PBL) model. The data of this research are collected through observation and test. The prerequisite test shows both homogeneus class and normally distributed. $\mathrm{T}$ test using $\mathrm{t}$ test Independent Sample Test shows $t_{\text {count }}>t_{\text {tabel }}$ that is 3,840 $>1,998$ and significant $0,000<0,05$ which means $\mathrm{H}_{0}$ rejected and $\mathrm{H}_{a}$ accepted. This shows a significant difference in effectiveness. Furthermore, the gain normality test shows that the Problem Posing model is more effective than Problem Based Learning (PBL) model of mathematical problem solving skill.
\end{abstract}

Keywords: PBL, Problem Posing, Problem Solving Skill. 
pembelajaran yang interaktif, menantang, memotivasi siswa untuk berpartisipasi secara aktif serta kemandirian sesuai dengan bakat, minat, dan perkembangan psikologis siswa (Peraturan Pemerintah Nomor 23 Tahun 2013 Tentang Standar Nasional Pendidikan).

Oleh karena itu, setiap satuan pendidikan menerapkan Kurikulum 2013 yang menuntut siswa untuk aktif, kreatif, dan inovatif dalam setiap pemecahan masalah yang dihadapi (Kurniasih, 2014). Model pembelajaran berbasis masalah sangat disarankan dalam kurikulum 2013 karena mampu mengarahkan siswa untuk menggali informasi berdasarkan pengalaman dan berorientasi pada masalah. Model pembelajaran berbasis masalah yang dapat diterapkan pada pembelajaran sekolah dasar adalah Problem Based Learning dan Problem Posing.

Problem Based Learning menjadi model pembelajaran yang melibatkan siswa dalam memecahkan masalah dengan awal pembelajaran menyajikan masalah nyata kemudian dipecahkan melalui penyelidikan (Ngalimun, 2013). Karakteristik Problem Based Learning menurut Sanjaya (2010) yaitu menuntut siswa aktif dalam pembelajaran (aktif berpikir, berkomunikasi, mengumpulkan data, dan menyimpulkan), aktivitas pembelajaran ditujukan untuk menyelesaikan masalah, dan pemecahan masalah dituntut menggunakan pendekatan ilmiah. Sedangkan Irwan (dalam Nugroho, 2015) menyatakan bahwa Problem Posing menuntut siswa untuk merumuskan dan membuat soal dari situasi yang diberikan dan penyelesaiannya dirancang sendiri, sehingga memungkinkan siswa dalam mengembangkan pola pikir matematis. Adapun karakteristik Problem Posing yaitu siswa sebagai subjek belajar, mengutamakan potensi siswa dalam pemecahan masalah, dan memberikan tantangan bagi siswa pada setiap pembelajaran (Thobroni dan Mustofa, 2012).

Berdasarkan karakteristik dari kedua model dapat dilihat bahwa keduanya mampu mengasah kemampuan pemecahan masalah. Slavin dalam Indarwati, Wahyudi, dan Ratu (2014) menyatakan bahwa pemecahan masalah merupakan penerapan pengetahuan dan keterampilan untuk mencapai tujuan secara tepat. Selanjutnya, Polya (1973) mengidentifikasi aspek pemecahan masalah terdiri dari memahami masalah, membuat rencana, melaksanakan rencana, dan mengecek kembali. Permasalahan yang dipecahkan tidak terlepas dari kehidupan seharihari, seperti pembelajaran matematika pada materi pecahan yang hanya dipecahkan menggunakan rumus tanpa memahami konsepnya. Selain itu siswa kesulitan dalam mengubah soal cerita pecahan menjadi bentuk simbolik matematik. Siswa juga kesulitan apabila diminta menuliskan pembuktian jawaban karena tidak memahami proses penyelesaiannya. Hal ini sejalan dengan realita yang terjadi di Sekolah Dasar yang sudah menerapkan Kurikulum 2013 namun siswa belum terlibat aktif dalam pembelajaran. Pada proses pembelajaran guru menjelaskan kemudian siswa menjadi penerima dan penghafal rumus. Apabila diberikan soal yang bervariasi siswa akan kesulitan dalam memecahkan soal karena tidak memahami konsep. Sehingga perlu adanya penerapan model pembelajaran berbasis masalah yang dapat mengembangkan kemampuan pemecahan masalah dan menuntut siswa aktif dalam pembelajaran.

Banyak penelitian yang telah dilakukan terkait keefektifan model Problem Based Learning. Penelitian Nasir (2016) menunjukkan bahwa Problem Based Learning efektif dalam meningkatkan kemampuan pemecahan masalah siswa. Sejalan dengan penelitian oleh Ruchaedi dan Baehaki (2016) menyatakan bahwa Problem Based Learning mampu meningkatkan kemampuan pemecahan masalah. Terlihat dari peningkatan kemampuan pemecahan masalah meningkat lebih baik dibandingkan siswa yang mendapatkan pembelajaran matematika secara konvensional. Sedangkan penelitian mengenai Problem Posing yang dilakukan oleh Susanti, Sukestiyarno, dan Sugiharti (2012) menyatakan keefektifan Problem Posing dalam pembelajaran. 
Terlihat dari rata-rata kelas eksperimen yang lebih tinggi dari kelas kontrol. Rata-rata kelas dapat menjadi bukti efektivitas Problem Posing dalam pembelajaran. Hal ini sejalan dengan penelitian yang dilakukan oleh Guntara, Murda, dan Rati (2014) bahwa terdapat perbedaan yang signifikan antara penerapan Problem Posing dengan pembelajaran langsung. Problem Posing lebih efektif dibandingkan pembelajaran langsung.

Berdasarkan penelitian yang sudah dilakukan mengenai model pembelajaran Problem Based Learning dan Problem Posing menunjukkan kesamaan bahwa keduanya efektif dalam pemecahan masalah matematika. Namun beberapa pebelitian dengan model Problem Posing dan Problem Based Learning menggunakan siswa SMP dan SMA sebagai sampel. Sehingga muncul suatu keraguan terkait keefektifan kedua model ditinjau dari kemampuan pemecahan masalah matematika kelas V SD.

\section{Metode}

Jenis Penelitian.

Jenis penelitian yang dilakukan adalah eksperimen. Pada penelitian eksperimen terdapat kelas kontrol dan kelas eksperimen. Desain penelitian yang digunakan adalah quasi eksperimental design dengan bentuk pola nonequvalent control group design. Desain penelitian ini diawali dengan melakukan pretes terlebih dahulu pada kelas kontrol maupun kelas eksperimen. Kemudian setelah dilakukan treatment, kelas kontrol maupun kelas eksperimen diberikan postes untuk mengetahui ada atau tidaknya akibat yang timbul dari treatment antara model pembelajaran Problem Based Learning dan Problem Posing. Gambaran desain penelitian Nonequvalent Control Group Design menurut Mc. Millan dan Schumacher (2001) disajikan pada tabel 1.

Tabel 1. Nonequvalent Control Group Design

\begin{tabular}{cccc}
\hline Group & Pretes & Treatment & Postes \\
\hline Kelas Eksperimen & $\mathrm{O}_{1}$ & $\mathrm{X}_{1}$ & $\mathrm{O}_{2}$ \\
\hline Kelas Kontrol & $\mathrm{O}_{3}$ & $\mathrm{X}_{2}$ & $\mathrm{O}_{4}$ \\
\hline
\end{tabular}

Untuk mnegetahui perbedaan efektivitas antara kelas eksperimen dan kelas kontrol dilakukan dengan uji normalitas N-Gain dengan persamaan :

$$
\mathrm{N}-\text { Gain }=\frac{\text { Spostes }- \text { Spretes }}{\text { Smax }- \text { Spretes }}
$$

Pengambilan sampel dilakukan dengan teknik probability sampling jenis cluster sampling. Sampel yang terpilih yaitu UPTD SPF SD Negeri Bringin 01 sebagai kelas kontrol dan UPTD SPF SD Negeri Bringin 02 sebagai kelas eksperimen. UPTD SPF SD Negeri Bringin 01 terletak di Jl. Diponegoro 54 Bringin, Kabupaten Semarang, Provinsi Jawa Tengah. Sekolah ini memiliki kelas pararel mulai dari kelas 1 sampai kelas 6 sehingga penelitian ini difokuskan pada kelas VB dengan jumlah siswa 28 yang terdiri dari 16 perempuan dan 12 laki-laki. Sedangkan UPTD SPF SD Negeri Bringin 02 terletak di Jl. Diponegoro 80 Bringin, Kabupaten Semarang, Provinsi Jawa Tengah. Penelitian dilakukan pada kelas V dengan jumlah siswa 37 yang terdiri dari 22 perempuan dan 15 laki-laki. 
Teknik dan Instrumen Pengumpulan Data.

Penelitian ini terdapat dua variabel yaitu variabel bebas dan variabel terikat. Variabel bebas pada penelitian ini adalah penggunaan model Problem Based Learning dan Problem Posing. Sedangkan variabel terikat pada penelitian ini adalah kemampuan pemecahan masalah. Pengumpulan data dilakukan dengan observasi dan tes. Observasi dimaksudkan untuk mengetahui proses pembelajaran Problem Based Learning dan Problem Posing berjalan sesuai dengan tahapannya. Observasi dilakukan dengan membuat lembar pengamatan yang berisikan indikator kegiatan guru saat melakukan pembelajaran. Sedangkan tes dilakukan untuk memperoleh data terkait kemampuan pemecahan masalah matematika siswa kelas $\mathrm{V}$ pada materi penjumlahan dan pengurangan pecahan. Tes yang diberikan berbentuk uraian. Langkahlangkah dalam pengumpulan data dilakukan dengan menyusun kisi-kisi soal, menyusun instrument penelitian, uji validitas dan reliabilitas, melakukan pretes dan postes, serta menganalisis data.

Teknik Analisis Data.

Analisis data digunakan untuk mengetahui hasil data berupa proses dan hasil. Proses yang dimaksud adalah proses pelaksanaan pembelajaran dengan penggunaan model Problem Based Learning dan Problem Posing. Analisis hasil digunakan untuk menganalisis hasil tes guna melihat efektivitas masing-masing model.

\section{Hasil dan Pembahasan}

\section{Hasil Penelitian}

Analisis Proses Pembelajaran.

Berdasarkan perhitungan presentase keterlaksanaan proses pembelajaran pada kelas eksperimen dengan model Problem Posing sebesar 90\%. Sedangkan keterlaksanaan proses pembelajaran pada kelas kontrol dengan model $P B L$ sebesar $91 \%$. Hal ini menunjukkan bahwa presentase keterlaksanaan proses pembelajaran kelas kontrol lebih besar dibandingkan kelas eksperimen. Hal ini dikarenakan beberapa kegiatan pada pendahuluan tidak terlaksana. Namun pada kegiatan inti terlaksana dengan baik dan kondusif.

Analisis Hasil Belajar.

Data yang diperoleh dari penelitian ini adalah data pretes dan postes kemampuan pemecahan masalah. Komprasi hasil pengukuran kemampuan pemecahan masalah disajikan pada tabel 2.

Tabel 2. Komprasi Hasil Pengukuran Kemampuan Pemecahan Masalah

\begin{tabular}{|c|c|c|c|}
\hline \multirow[t]{2}{*}{ Pengukuran } & \multicolumn{2}{|c|}{ Rata-rata nilai (mean) } & \multirow[t]{2}{*}{ Selisih } \\
\hline & Eksperimen & Kontrol & \\
\hline Pretes & 63.49 & 60.25 & 3.24 \\
\hline Postes & 75.22 & 68.61 & 6.61 \\
\hline
\end{tabular}

Berdasarkan hasil data komprasi rata-rata pada tabel 2 menunjukkan rata-rata nilai pretes antara kelas kontrol dan kelas eksperimen 3,24. Sedangkan untuk rata-rata skor postes antara kelas eksperimen yang diberikan treatment model Problem Posing dan kelas kontrol yang diberikan treatment model PBL memiliki selisih sebesar 6,61. Adapun komprasi data antara kelas eksperimen dan kelas kontrol pada gambar 1. 


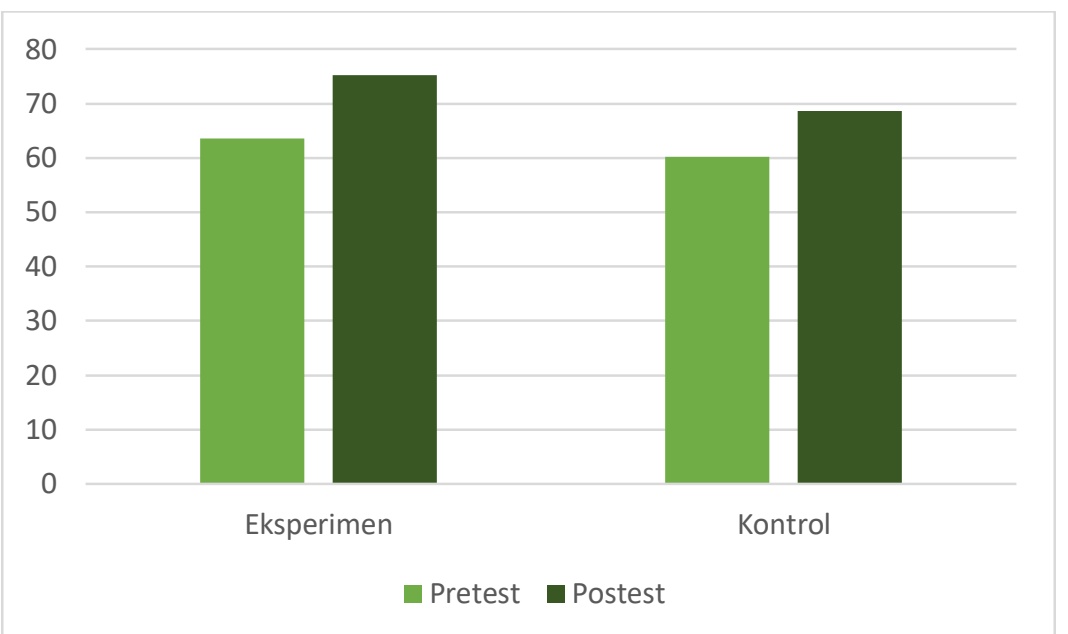

Gambar 1. Komprasi Hasil Pengukuran Kemampuan Pemecahan Masalah

Berdasarkan gambar diagram komprasi hasil pengukuran kemampuan pemecahan masalah dapat diketahui bahwa adanya peningkatan pada kedua kelas, yaitu kelas eksperimen dengan treatment Problem Posing dan kelas kontrol dengan treatment PBL.

Penelitian ini melakukan uji normalitas dan uji homogenitas sebagai uji prasyarat. Uji prasyarat dilakukan sebelum melakukan uji beda. Uji normalitas digunakan untuk menentukan data yang dikumpulkan berdistribusi normal atau tidak. Uji normalitas disajikan pada tabel 3.

Tabel 3. Uji Normalitas Kelas Eksperimen dan Kelas Kontrol

\begin{tabular}{|c|c|c|c|c|c|c|c|}
\hline & \multirow{2}{*}{ Kelas } & \multicolumn{3}{|c|}{ Kolmogorov-Smirnov $^{a}$} & \multicolumn{3}{|c|}{ Shapiro-Wilk } \\
\hline & & Statistic & df & Sig. & Statistic & df & Sig. \\
\hline \multirow{4}{*}{$\begin{array}{l}\text { Hasil tes } \\
\text { kemampuan } \\
\text { pemecahan } \\
\text { masalah }\end{array}$} & $\begin{array}{l}\text { Pretes } \\
\text { eksperimen } \\
\text { (Problem Posing) }\end{array}$ & .123 & 37 & .173 & .952 & 37 & .110 \\
\hline & $\begin{array}{l}\text { Postes } \\
\text { eksperimen } \\
\text { (Problem Posing) }\end{array}$ & .133 & 37 & .094 & .963 & 37 & .250 \\
\hline & $\begin{array}{ll}\text { Pretes } & \text { kontrol } \\
(P B L) & \\
\end{array}$ & .129 & 28 & $.200^{*}$ & .941 & 28 & .115 \\
\hline & $\begin{array}{ll}\text { Postes } & \text { kontrol } \\
(P B L) & \\
\end{array}$ & .148 & 28 & .121 & .932 & 28 & .068 \\
\hline
\end{tabular}

Uji normalitas dengan teknik shapiro-walk menggunakan bantuan SPSS 20.0 for windows, jika nilai signifikan $<0,05$ maka data tidak berdistribusi normal dan jika nilai signifikan > 0,05 maka data berdistribusi normal. Berdasarkan data uji normalitas kelas eksperimen dan kelas kontrol di atas menunjukkan bahwa data berdistribusi normal.

Selain uji normalitas dilakukan pula uji homogenitas. Uji homogenitas dilakukan untuk mengetahui sampel kelas eksperimen dan kelas kontrol memiliki varian yang sama atau tidak. Data disebut homogen apabila nilai signifikasi $>0,05$ dan data disebut tidak homogen apabila nilai signifikasi < 0,05. Uji homogenitas sebelum treatment disajikan pada tebel 4 . 
Tabel. 4 Uji Homogenitas Sebelum Treatment

\begin{tabular}{llcccc}
\hline & & $\begin{array}{c}\text { Levene } \\
\text { Statistic }\end{array}$ & df1 & df2 & Sig. \\
\hline \multirow{3}{*}{$\begin{array}{l}\text { Hasil pretes } \\
\text { kemampuan } \\
\text { pemecahan masalah }\end{array}$} & Based on Mean & .196 & 1 & 63 & .659 \\
\cline { 2 - 6 } & Based on Median & .205 & 1 & 63 & .652 \\
\cline { 2 - 6 } & $\begin{array}{l}\text { Based on Median and } \\
\text { with adjusted df }\end{array}$ & .205 & 1 & 62.512 & .652 \\
\cline { 2 - 6 } & $\begin{array}{l}\text { Based on trimmed } \\
\text { mean }\end{array}$ & .160 & 1 & 63 & .690 \\
\hline
\end{tabular}

Berdasarkan tabel di atas diperoleh hasil uji homogenitas menggunakan metode Levene's Test dengan memilih salah satu interpretasi statistik berdasarkan rata-rata (Based on Mean). Tabel di atas menunjukkan hasil uji homogenitas sebelum dilakukan treatment memperoleh nilai signifikasi 0,659 dimana > 0,05 yang artinya kelas eksperimen dan kelas kontrol memiliki varian yang sama atau disebut homogen.

Tabel 5. Uji Homogenitas Setelah Treatment

\begin{tabular}{llcccc}
\hline & & $\begin{array}{c}\text { Levene } \\
\text { Statistic }\end{array}$ & df1 & df2 & Sig. \\
\hline $\begin{array}{l}\text { Hasil postes } \\
\text { kemampuan } \\
\text { pemecahan } \\
\text { masalah }\end{array}$ & Based on Mean & 2.595 & 1 & 63 & .112 \\
\cline { 2 - 6 } & Based on Median & 2.125 & 1 & 63 & .150 \\
\cline { 2 - 6 } & $\begin{array}{l}\text { Based on Median and with } \\
\text { adjusted df }\end{array}$ & 2.125 & 1 & 62.998 & .150 \\
\cline { 2 - 6 } & Based on trimmed mean & 2.603 & 1 & 63 & .112 \\
\hline
\end{tabular}

Berdasarkan tabel di atas diperoleh hasil uji homogenitas dengan metode Levene's Test. Hasil pada tabel uji homogenitas setelah treatment menunjukkan nilai signifikasi 0,112 dimana > 0,05 yang artinya kelas eksperimen dan kelas kontrol terdapat varian yang sama atau disebut homogen.

Berdasarkan uji prasyarat yang telah dilakukan, dapat disimpulkan data berdistribusi normal dan bersifat homogen. Selanjutnya dilakukan analisis uji T menggunakan SPSS 20.0 for windows dengan independent sample T test. Uji T test dilakukan untuk mengetahui ada tidaknya perbedaan efektivitas antara kelas eksperimen dan kelas kontrol ditinjau dari kemampuan pemecahan masalah. Hasil analisis uji T disajikan pada tabel 6.

Tabel 6. Hasil Analisis Uji T dengan Independent Sample T-Test

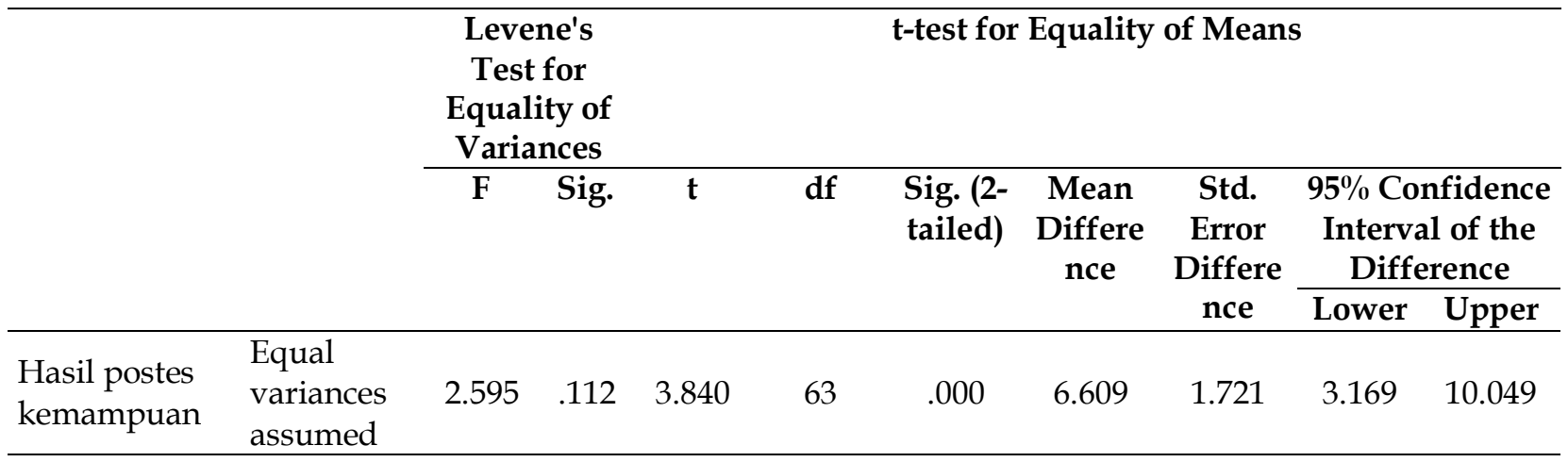




\begin{tabular}{lllllllll}
\hline $\begin{array}{l}\text { pemecahan } \\
\text { masalah }\end{array}$ & $\begin{array}{l}\text { Equal } \\
\text { variances } \\
\text { not } \\
\text { assumed }\end{array}$ & 3.930 & 62.166 & .000 & 6.609 & 1.682 & 3.248 & 9.970 \\
& & & & & & & & \\
\hline
\end{tabular}

Hasil dari uji $\mathrm{T}$ dengan independent sample $T$ test menunjukkan bahwa hasil thitung sebesar 3,840 dengan signifikasi sebesar 0,000. Terlihat pula perbedaan antara rata-rata kelompok mean diference sebesar 6,609, ttabel yang diperoleh dari data di atas adalah 1,998. Sehingga dapat disimpulkan bahwa $\mathrm{H}_{0}$ ditolak dan $\mathrm{H}_{a}$ diterima, artinya terdapat perbedaan efektivitas pada penerapan Problem Based Learning dan Problem Posing ditinjau dari kemampuan pemecahan masalah matematika kelas V SD.

Selanjutnya dilakukan uji N-Gain untuk mengetahui perbedaan efektivitas model Problem Based Learning dan Problem Posing. Berdasarkan hasil uji N-Gain kelas eksperimen menunjukkan adanya peningkatan sebesar 0,32 yang artinya rata-rata kelas eksperimen mengalami peningkatan pada kategori sedang. Sedangkan hasil rata-rata kelas kontrol menunjukkan peningkatan sebesar 0,20 yang rata-rata kelas kontrol mengalami peningkatan pada kategori rendah. Sehingga dapat disimpulkan bahwa peningkatan lebih tinggi terjadi pada kelas eksperimen.

\section{Pembahasan}

Penelitian ini menggunakan model Problem Posing dan Problem Based Learning yang terbukti dapat meningkatkan kemampuan pemecahan masalah siswa dalam pelajaran matematika. Namun Problem Posing mengalami peningkatan lebih tinggi dibandingkan Problem Based Learning. Pada pembelajaran dengan Problem Posing siswa tidak hanya memecahkan masalah dalam kehidupan sehari-hari. Akan tetapi siswa diajarkan untuk membuat soal serta penyelesaiannya dengan cara yang sederhana. Secara berkelompok siswa mengumpulkan data untuk memecahkan permasalahan kemudian membuat beberapa soal yang menantang. Sedangkan pembelajaran dengan model Problem Based Learning siswa hanya menyelesaikan persoalan yang diberikan guru. Siswa secara berkelompok mengumpulkan data untuk menyelesaikan permasalahan.

Keberhasilan yang diperoleh dalam peningkatan kemampuan pemecahan masalah siswa kelas V dalam pelajaran matematika dengan model Problem Posing dan Problem Based Learning dipengaruhi oleh pengembangan ide pada setiap aspek kemampuan pemecahan masalah. Pemecahan masalah merupakan suatu usaha menemukan jalan keluar dari kesulitan atau masalah yang tidak rutin sehingga masalah tersebut tidak lagi menjadi masalah (Wahyudi dan Anugraheni, 2017). Pengembangan ide dalam memecahkan masalah dapat berupa ide baru yang bersifat asli ciptaan sendiri, maupun modifikasi dari berbagai ide yang sudah ada sebelumnya. Dalam proses pemecahan masalah terkait persoalan yang bersifat menantang tidak dapat diselesaikan dengan prosedur rutin yang sudah biasa dilakukan atau diketahui (Nazwandi, 2010).

Selain itu, penelitian ini melakukan pretes dan postes untuk mengetahui adanya peningkatan nilai yang dicapai siswa. Keberhasilan dalam penelitian ini juga dipengaruhi oleh signifikan nilai setiap kelas pada sebelum dan sesudah diberikan treatment dengan model pembelajaran yang berbeda. Maka dari itu, dilakukan analisis untuk mengetahui bahwa model Problem Posing mengalami peningkatan lebih tinggi dibandingkan model Problem Based Learning. 
Berdasarkan hasil penelitian ini, dapat disimpulkan bahwa Problem Posing lebih efektif untuk mengukur kemampuan pemecahan masalah siswa kelas $\mathrm{V}$ pada pelajaran matematika dibandingkan dengan model PBL. Hasil ini menguatkan penelitian Saptono, Wahyudi, dan Indarini (2018) yang menyatakan bahwa Problem Posing meningkatkan kemampuan pemecahan masalah dalam pembelajaran matematika. Begitu juga dengan penelitian yang dilakukan Guntara, Murda, dan Rati (2014) dengan hasil model Problem Posing lebih efektif dalam pembelajaran matematika SD dibandingkan pembelajaran langsung. Sejalan dengan penelitian Aristiyowati (2014) dengan hasil yang menyatakan Problem Posing lebih efektif dibandingkan pembelajaran konvensional pada pembelajaran matematika dengan alat peraga jam sudut. Pembelajaran dengan model Problem Posing perlu digunakan sesering mungkin agar terlatih dalam memecahkan suatu masalah atau persoalan dalam kehidupan sehari-hari.

\section{Simpulan}

Berdasarkan uraian hasil penelitian dan pembahasan dapat disimpulkan bahwa terdapat perbedaan pembelajaran dengan model Problem Posing lebih efektif dibandingkan model Problem Based Learning untuk mengukur kemampuan pemecahan matematika siswa kelas V. Dilihat dari rata-rata postes Problem Posing sebesar 75,22 dengan nilai mengalami peningkatan 0,32. Sedangkan pembelajaran dengan model Problem Based Learning memperoleh nilai rata-rata postes sebesar 68,61 dengan nilai N-Gain mengalami peningkatan 0,2.

\section{Daftar Rujukan}

Aristiyowati, H. (2014). Efektivitas model problem posing menggunakan alat peraga jam sudut terhadap hasil belajar matematika siswa kelas V MIN Mlaten Mijen Demak pada materi pengukuran sudut. (Doctoral dissertation, UIN Walisongo).

Guntara, I. W., Murda, I. N., \& Rati, N. W. (2014). Pengaruh Model Pembelajaran Problem Posing terhadap Hasil Belajar Matematika di SD Negeri Kalibukbuk. MIMBAR PGSD Undiksha, 2(1).

Indarwati, D., Wahyudi, W., \& Ratu, N. (2014). Peningkatan Kemampuan Pemecahan Masalah Matematika Melalui Penerapan Problem Based Learning Untuk Siswa Kelas V Sd. Satya Widya, 30(1), 17-27.

Kurniasih, Sani. (2014). Strategi-Strategi Pembelajaran. Bandung: Alfabeta.

McMillan, J.H. and Schumacher, S. (2001). Research in Education. New York: Longman, Inc.

Nasir, M. (2016). Efektivitas Model Pembelajaran Berbasis Masalah (Problem Based Learning) Terhadap Kemampuan Pemecahan Masalah Siswa Pada Pelajaran Matematika. Muallimuna: Jurnal Madrasah Ibtidaiyah, 1(2), 1-19.

Nazwandi. (2010). Pemecahan Ma-salah dalam Pembelajaran Matematika. Modul Mata Kuliah Evaluasi Pembelajaran. FKIP UMS.

Ngalimun. (2013). Strategi Dan Modal Pembelajaran. Yogyakarta: Aswaja Presindo. 
Nugroho, H. P. (2015). Keefektifan Problem Based Learning Dengan Strategi Problem Posing Pada Pencapaian Kemampuan Pemecahan Masalah Dan Disposisi Matematik Siswa (Doctoral Dissertation, Universitas Negeri Semarang).

Pemerintah, P. Nomor 23 Tahun 2013 tentang Standar Nasional Pendidikan. Jakarta: Departemen Pendidikan Nasional RI.

Polya, G. (1973). How to Solve it. New Jersey: Princeton University Press.

Ruchaedi, D., \& Baehaki, I. (2016). Pengaruh Problem Based Learning (PBL) terhadap Kemampuan Heuristik Pemecahan Masalah dan Sikap Matematis Siswa Sekolah Dasar. Jurnal Cakrawala Pendas, 2(2).

Sanjaya, Wina. (2010). Strategi Pembelajaran Berorientasi Standart Proses. Jakarta: Prenada Media.

Saptono, B., Wahyudi, W., \& Indarini, E. (2018). Penerapan Motode Pembelajaran. Problem Posing Untuk Meningkatkan Kemampuan Pemecahan Masalah Pengukuran Sudut Dengan Busur Derajat Siswa Kelas 4 Sdn Barukan 02. Kalam Cendekia Pgsd Kebumen, 6(4.1).

Sintawati, M. (2015). Keefektifan Problem Based Learning dan Problem Posing dalam Pembelajaran Matematika. In Seminar Nasional Matematika dan Pendidikan Matematika UNY.

Susanti, E. L., Sukestiyarno, Y. L., \& Sugiharti, E. (2012). Efektivitas Pembelajaran Matematika Dengan Metode Problem Posing Berbasis Pendidikan Karakter. Unnes Journal of Mathematics Education, 1(1).

Thobroni \& Mustofa. (2012). Belajar dan Pembelajaran. Jogjakarta: Ar-ruzz Media.

Wahyudi, I. A., \& Anugraheni, I. (2017). Strategi Pemecahan Masalah Matematika. Salatiga: Satya Wacana University Press. 